Copy-edited by LD Todd

\title{
Viral infection of prokaryotic plankton during early formation of the North West Atlantic Deep Water
}

\author{
Markus G. Weinbauer ${ }^{1, *}$, Christian Griebler ${ }^{2}$, Hendrik M. van Aken ${ }^{3}$, Gerhard J. Hernd1 ${ }^{4,5}$
}

${ }^{1}$ Sorbonne Universités, UPMC Univ Paris 06, CNRS, Laboratoire d'Océanographie de Villefranche (LOV), 181 Chemin du Lazaret, 06230 Villefranche-sur-Mer, France

${ }^{2}$ Department of Limnology \& Bio-Oceanography, University of Vienna, Althanstrasse 14, 1090

Vienna, Austria

${ }^{3}$ Department of Physical Oceanography, Royal Netherlands Institute for Sea Research (NIOZ), 1790 AB Den Burg, The Netherlands

${ }^{4}$ Department of Marine Biology, University of Vienna, Althanstrasse 14, 1090 Vienna, Austria ${ }^{5}$ Department of Biological Oceanography, Royal Netherlands Institute for Sea Research (NIOZ), 1790 AB Den Burg, The Netherlands

*Corresponding author: wein@,obs-vlfr.fr

Running head: Weinbauer et al.: Viruses in the North Atlantic Deep Water

ABSTRACT: Viral abundance was assessed in different water masses of the NW Atlantic, and the development of viral abundance, lytic viral infection and lysogeny was followed for the first ca. $5000 \mathrm{~km}$ (corresponding to ca. $50 \mathrm{yr}$ in the oceanic conveyor belt) of the western branch of the North Atlantic Deep Water (NADW). Viral abundance was significantly higher in the $100 \mathrm{~m}$ layer than in the NADW (2400-2700 m depth) and the Denmark Strait Overflow Water (2400-3600 m depth). The virus-to-prokaryote ratio (VPR) increased with depth, ranging from 32-43 for different water masses of the bathypelagic ocean, thus corroborating the enigma of high viral abundance in the dark ocean. The $\mathrm{O}_{2}$-minimum layer $(250-600 \mathrm{~m})$ also showed high viral abundance and VPRs. Viral abundance, a viral subgroup and VPRs decreased in a non-linear form with distance from the NADW origin. Viral production (range: $0.2-2.4 \times 10^{7}$ viruses $1^{-1}$ ) and the fraction of lytically 
infected cells (range: 1-22\%) decreased with increasing distance from the formation site of the NADW. Conservative estimations of virus-mediated mortality of prokaryotes in the NADW averaged $20 \pm 12 \%$. The fraction of the prokaryotic community with lysogens (i.e. harboring a functional viral DNA) in the NADW averaged $21 \pm 14 \%$. Hence, we conclude that (1) viral abundance and subgroups differ between water masses, (2) virus-mediated mortality of prokaryotes as well as lysogeny are significant in the dark ocean and (3) the lysogenic life strategy becomes more important than the lytic life style during the early formation of the NADW.

KEY WORDS: NADW · Thermohaline circulation · Dark ocean · Viral production · Lysogeny · Microorganisms

\section{INTRODUCTION}

It is now well accepted that viruses represent the most abundant 'life forms' in the ocean and that viral lysis is a major mortality factor for marine microorganisms in the upper ocean (e.g. (Wommack \& Colwell 2000, Weinbauer 2004, Winter et al. 2010, Zimmerman et al. 2020). Lysis not only causes cell death but also releases the cell contents as dissolved organic matter (DOM) and converts cell walls into small detritus; this viral shunt plays an important role in the cycling of carbon and nutrients (Gobler et al. 1997, Wilhelm \& Suttle 1999, Brussaard et al. 2008, Weinbauer et al. 2009b) and in carbon export by the biological pump (Weinbauer et al. 2009a, Yamada et al. 2018).

During the last 1-2 decades, viral ecology of the dark ocean has been increasingly studied. Data sets are available on viral abundance (VA) and production (VP) in the water column of the dark realm of the Atlantic Ocean (Parada et al. 2007, De Corte et al. 2010, 2012, 2016, Muck et al. 2014, Winter et al. 2018), Pacific and Southern Ocean (Li et al. 2014, Yang et al. 2014),

Mediterranean Sea (Winter et al. 2009, Umani et al. 2010) and from a circumnavigation expedition (Lara et al. 2017). Some of these studies reported that prokaryotic abundance (PA) decreased faster with depth than VA, thus resulting in a high virus-to-prokaryote ratio (VPR) in the bathypelagic and abyssopelagic ocean; however, there are also exceptions (Winter et al. 2009, Lara et al. 2017). This presents an enigma, since host abundances are 1-2 orders of magnitude lower in deep than in surface waters, which should — according to theory—result in a reduced contact rate between viruses and hosts and thus in reduced viral infection and production (Murray \& Jackson 1992). However, it has been demonstrated that lytic VP is a major source of prokaryotic mortality in the dark ocean. Data on viral production and virus-mediated mortality in the dark ocean are available for the Chukchi Sea (Steward et al. 1996), Mediterranean Sea (Weinbauer et al. 2003, Winter et al. 
2009, Umani et al. 2010), Atlantic Ocean (Parada et al. 2007, De Corte et al. 2010, 2012, Muck et al. 2014) and Pacific Ocean (Li et al. 2014, Yang et al. 2014).

Lysogeny, i.e. the phenomenon that prokaryotic cells can harbour a provirus (viral DNA) which can be induced by specific environmental conditions, has also been studied in the dark ocean (Weinbauer et al. 2003, De Corte et al. 2010, 2012). It is believed that lysogeny is established when the encounter rate between phages and host cells is low or when viral decay rates are high, i.e. in conditions unfavourable to hosts (e.g. Stewart \& Levin 1984, Weinbauer 2004). Using isolates, it has been argued that a high host density destabilizes the interaction between a lytic phage and its host (Bohannan \& Lenski 1997). Therefore, development of lysogeny would stabilize this interaction and support the survival of the phage line (Williams 1994). In this case, lysogeny might also be beneficial in high host-density environments (Weinbauer 2004). Indeed, it has been suggested that lysogeny can dominate when host abundance and production is high, i.e. in conditions favourable for hosts ('piggyback-the-winner' model; Knowles et al. 2016). Metagenomic studies suggest that provirus gene induction, and thus lysogeny, is the predominant life strategy in the deep sea (Williamson et al. 2008, Mizuno et al. 2016). Some studies have reported that lysogeny and inducible lysogenic VP typically increase with water depth compared to lytic VP; however, other studies have also reported the inverse trend. The inducing agents of lysogenic bacteria are not known for the dark ocean but it has been suggested that mixing of water masses can cause provirus induction (Winter et al. 2018).

Depth-related variations in prokaryotic biomass and production have been summarized (e.g. Nagata et al. 2000, Arístegui et al. 2009). In contrast to such depth trends, the functioning of the global ocean is primarily explained by the lateral transport of physically distinct water masses (thermohaline circulation) (Broecker 1997). Thermohaline circulation begins in the GreenlandIceland-Norwegian (GIN) Sea. Differences in prokaryotic activity and community composition were investigated in distinct water masses of this North Atlantic Deep Water (NADW) during several cruises (Reinthaler et al. 2006, Teira et al. 2006, Agogué et al. 2011). Here, we investigated VA and distinct viral groups as assessed by flow cytometry in the different water masses and followed the development of VA, VP, lytic viral infection and lysogeny in the western branch of the NADW during the TRNSAT-II cruise. The water mass was sampled from close to its formation for about $5500 \mathrm{~km}$, thus covering approximately the first $50 \mathrm{yr}$ of the NADW in the oceanic conveyor belt system.

\section{MATERIALS AND METHODS}

\subsection{Study site and sampling}


The western branch of the NADW was followed with the R/V 'Pelagia' from near its source of origin in the GIN Sea for over ca. $5000 \mathrm{~km}$ (II. 1). The TRANSAT-II cruise (May 2003) followed a track from $62.5^{\circ} \mathrm{N}, 30.3^{\circ} \mathrm{W}$ to $37.7^{\circ} \mathrm{N}, 69.7^{\circ} \mathrm{W}$ in the western basin of the North Atlantic, covering 34 stations (Fig. 1). The distance of the stations from the origin of the NADW was calculated using Ocean Data View (http://odv.awi.de). Water was collected with a CTD rosette sampler holding twenty four 121 no oxygen exchange (NOEX) bottles. Samples were taken from $100 \mathrm{~m}$ depth (subsurface layer [SSL]), the oxygen minimum zone and the main deep water masses encountered during the cruise. The main water masses sampled were the Labrador Sea Water (LSW), the NADW and the Denmark Strait Overflow Water (DSOW). These specific water masses were identified based on their temperature and salinity characteristics (see Table 1) and their oxygen concentrations, using a Seabird SBE43 oxygen sensor mounted on the CTD frame. For more details of the sampling and water mass characterization, see Reinthaler et al. (2006) and Teira et al. (2006). From these water masses, seawater samples were collected for physical-chemical parameters, PA, VA and VP and to estimate lytic and lysogenic infection.

\subsection{Methods for data used from previous publications}

The following data were obtained from previous publications on the TRANSAT-II cruise. For details and references see Reinthaler et al. (2006) and Teira et al. (2006). Briefly, apparent oxygen utilization (AOU) was calculated as the difference between the saturation oxygen concentration and the observed oxygen concentration. The concentrations of inorganic nutrients $\left(\mathrm{NH}_{4}, \mathrm{NO}_{3}, \mathrm{NO}_{2}\right.$ and $\left.\mathrm{PO}_{4}\right)$ were determined immediately after sample collection and gentle filtration through $0.2 \mathrm{~mm}$ filters (Acrodisc; Gelman Science) in a TRAACS autoanalyzer system. $\mathrm{NH}_{4}$ was detected with the indo-phenol blue method $(\mathrm{pH} 10.5)$ at $630 \mathrm{~nm} . \mathrm{NO}_{2}$ was determined after diazotation with sulfanilamide and $\mathrm{N}$-(1-naphtyl)-ethylene diammonium-dichloride as the reddish-purple dye complex at $540 \mathrm{~nm}$. $\mathrm{NO}_{3}$ was reduced in a copper cadmium coil to $\mathrm{NO}_{2}$ (with imidazole as a buffer) and then measured as $\mathrm{NO}_{2}$. $\mathrm{PO}_{4}$ was determined via the molybdenum blue complex at $880 \mathrm{~nm}$.

For enumeration of heterotrophic prokaryotes, samples $(1 \mathrm{ml})$ of unfiltered seawater were fixed with 37\% $0.2 \mathrm{~mm}$ filtered (Acrodisc; Gelman) formaldehyde ( $2 \%$ final concentration), stained with $0.5 \mathrm{ml}$ of SYBR Green I (Molecular Probes) at room temperature in the dark for $15 \mathrm{~min}$ and subsequently analyzed on a FACSCalibur flow cytometer (BD Biosciences). Counts were performed with an argon laser at $488 \mathrm{~nm}$ set at an energy output of $15 \mathrm{~mW}$. Prokaryotic cells were enumerated according to their right-angle light scatter and green fluorescence measured at $530 \mathrm{~nm}$. 
Prokaryotic heterotrophic production (PHP) in seawater was measured by ${ }^{3} \mathrm{H}$-leucine incorporation (specific activity: $595.731010 \mathrm{~Bq} \mathrm{mmol}^{-1}$; final concentration: $10 \mathrm{nmol} \mathrm{l}^{-1}$ ). Two 10-40 $\mathrm{ml}$ samples and 1 blank were incubated in the dark. The blank was fixed with concentrated $0.2 \mathrm{~mm}$ filtered formaldehyde (4\% final concentration, v/v) $10 \mathrm{~min}$ prior to adding the tracer. After incubating the samples and the blank at in situ temperature for 4-12 h, depending on the expected activity, the samples were fixed with formaldehyde ( $4 \%$ final concentration), filtered onto $0.2 \mathrm{~mm}$ nitrocellulose filters (Millipore HA; $25 \mathrm{~mm}$ diameter) and rinsed twice with $5 \mathrm{ml}$ ice-cold 5\% trichloroacetic acid (Sigma Chemicals) for $5 \mathrm{~min}$. The filters were dissolved in $1 \mathrm{ml}$ ethylacetate, and after $10 \mathrm{~min}, 8 \mathrm{ml}$ of scintillation cocktail (Insta-Gel Plus; Canberra Packard) was added. The radioactivity incorporated into cells was counted in a liquid scintillation counter (Model 1212; LKB Wallac). Leucine incorporated into prokaryotic biomass was converted to carbon production using the theoretical conversion factor of $3.1 \mathrm{~kg} \mathrm{C} \mathrm{mol}^{-1} \mathrm{Leu}$, assuming a two-fold isotope dilution.

\subsection{Enumeration of viruses}

Water samples for viral enumeration were preserved with glutaraldehyde $(0.5 \%$ final concentration) at $4^{\circ} \mathrm{C}$ for $30 \mathrm{~min}$, then flash-frozen in liquid nitrogen and stored at $-80^{\circ} \mathrm{C}$ until analysis. Virus samples were diluted 20 -fold in autoclaved and $0.2 \mu \mathrm{m}$ prefiltered TE buffer (10 mmol $\mathrm{l}^{-1}$ Tris, $1 \mathrm{mmol}^{-1}$ EDTA, pH 8.0) and stained with SYBR Green I (Molecular Probes) (at a 20000 -fold dilution of the stock solution) in an $80^{\circ} \mathrm{C}$ water bath for $10 \mathrm{~min}$ before counting. Viruses were detected by their signatures in a side-scatter-versus-green-fluorescence (530 $\mathrm{nm}$ wavelength, fluorescence channel 1 of the instrument) plot and counted by flow cytometry (FACSCalibur; BD Biosciences) following the protocol of Brussaard et al. (2010). Data analysis was performed using BD Cell Quest Pro software version 4.0.2 (BD Biosciences). Viral subgroups V1, V2 and V3 were distinguished by increasing fluorescence intensity with settings for the different subgroups that were identical for all analyzed samples. The difference between replicates was typically better than $10 \%$.

\subsection{Burst size}

To assess in situ burst size (BS; i.e. the number of viruses released upon cell lysis), $50 \mathrm{ml}$ of the prokaryotic concentrates (see below) were preserved in glutaraldehyde $(0.5 \%$ final concentration), kept briefly at $4^{\circ} \mathrm{C}$ and then stored at $-80^{\circ} \mathrm{C}$ until analysis. Prokaryotic cells in thawed samples were collected by centrifugation onto formvar-coated transmission electron microscope (TEM) grids (copper, 400 mesh size) and stained with uranyl acetate (Weinbauer \& Suttle 1999). Duplicate grids were used for each sample. The minimum BS (BSmin) was estimated as the average from $>20$ visibly infected cells grid $^{-1}$. This number is a conservative estimate 
because viruses could still be assembled in the cells; therefore, a conversion was used to calculate maximum BS (BS $\max ): \mathrm{BS}_{\max }=1.41 \times \mathrm{BS}_{\min }+0.87$ (Parada et al. 2006).

\subsection{VP and infection of prokaryotic plankton}

VP, the fraction of infected cells (FIC) and the fraction of lysogenic cells (FLC) were estimated with a dilution technique (Wilhelm et al. 2002) using a modification described elsewhere (virus-reduction approach [VRA]: Weinbauer et al. 2002, 2010). Large water samples (150-200 1) were filtered through $0.8 \mathrm{~mm}$ pore-size polycarbonate filters (142 $\mathrm{mm}$ diameter; Millipore) and prokaryotes were concentrated using a Pellicon (Millipore) tangential flow filtration system equipped with a $0.2 \mu \mathrm{m}$ filter cartridge (Durapore; Millipore) as described in (Weinbauer et al. 2009b). The first 201 of the $0.2 \mu \mathrm{m}$ filtrate were processed with a $100 \mathrm{kDa}$ cutoff polysulfone cartridge (Prep-Scale/TFF; Millipore: $0.23 \mathrm{~m}^{2}$ nominal filter area, operated by a peristaltic pump at

$\mathrm{Pa}$ ) to produce virus-free water. Aliquots of the prokaryote concentrate were added to virusfree water to obtain roughly in situ abundance assuming (based on previous findings) that half of the prokaryotes were lost during the prefiltration and ultrafiltration steps. This procedure reduces contact rates between viruses and hosts and thus new infection. Incubations were performed in the dark at in situ temperature $\left(3.0^{\circ} \mathrm{C}\right)$ in duplicate $50 \mathrm{ml}$ sterile conical tubes for $24 \mathrm{~h}$. Samples were taken at incubation times $(t) 0,6,12,18$ and $24 \mathrm{~h}$. VP was calculated as:

$$
\mathrm{VP}=\left(\mathrm{VA}_{2}-\mathrm{VA}_{1}\right) /\left(t_{2}-t_{1}\right)
$$

where $\mathrm{VA}_{1}$ and $\mathrm{VA}_{2}$ are the viral abundances at incubation times $t_{1}$ and $t_{2}$, respectively. Note that individual incubations were treated separately and values at the start of incubations were not always used for calculations. Rather, the lowest viral abundance served as VA1 (Weinbauer et al. 2009b). Thus, $\mathrm{VA}_{1}$ and $\mathrm{VA}_{2}$ are the minimum and maximum of viral abundance in the incubation. VP was corrected for the changes in PA at the start of the experiment compared to in situ abundances.

Dividing the number of produced viruses by the BS yields the number of lysed cells and thus gives an estimate of FIC (Weinbauer et al. 2002), which was calculated by:

$$
\mathrm{FIC}=100\left(\mathrm{VA}_{2}-\mathrm{VA}_{1}\right) / \mathrm{BS} / \mathrm{PA}
$$

where PA is the prokaryotic abundance at the start of the experiment ( $\left.t_{1}\right)$. Virus-mediated mortality of prokaryotes (VMMP) was either calculated as:

$$
\mathrm{VMMPVP}_{\mathrm{v}}=100(\mathrm{VP} / \mathrm{BS} / \mathrm{PHP})
$$

or using FIC values and the model of Binder (1999) (VMMPFIC).

The FIC treatment also served as a control in the lysogeny bioassays. To induce the lytic cycle in lysogenic cells (containing a prophage), samples were treated with mitomycin C (Sigma 
Chemicals; final concentration: $0.5 \mu \mathrm{g} \mathrm{ml}^{-1}$; Paul \& Weinbauer 2010). The difference in VA between this treatment and the control is the number of induced viruses, which is divided by the BS to estimate the number of induced cells and thus the FLC. FLC was calculated as percentage by:

$$
\mathrm{FLC}=100\left(\mathrm{VA}_{\mathrm{MC}}-\mathrm{VAC}\right) / \mathrm{BS} / \mathrm{PA}
$$

where VAMC and VAC are the maximum difference in viral abundance at corresponding time points in mitomycin $\mathrm{C}$ and control treatments, respectively. Induced $\mathrm{VP}\left(\mathrm{VP}_{\mathrm{i}}\right)$ was calculated analogous to VP after by subtracting VAC from VAMC.

\subsection{Statistics}

Spearman rank correlations were used to assess the covariation of parameters, since some variables did not comply with normality even after logarithmic transformation. The non-parametric Kruskal-Wallis and Mann-Whitney tests were used for comparing specific parameters obtained in different water masses, since normality was not always attained; $\mathrm{p}<0.05$ (after applying a Bonferroni correction) was considered significant. To test a potential change of viral parameters with distance from the GIN Sea, regressions with linear, logarithmic, exponential and power functions were calculated; $p<0.05$ was considered significant. Statistics were performed with Aabel_3.

\section{RESULTS}

\subsection{Characterization of water masses}

Some basic physical-chemical characteristics of the main water masses sampled during the study are given in Table 1. More details can be found elsewhere (Teira et al. 2006). The LSW, characterized by low salinity, was clearly identifiable at depths between 700 and $2100 \mathrm{~m}$, except between 40 and $45^{\circ} \mathrm{N}$. The NADW (2000-3000 m) was identifiable by its salinity maximum (34.90-34.95) south of $60^{\circ} \mathrm{N}$. The DSOW underlying the NADW, with seawater temperature between 0.8 and $2.4^{\circ} \mathrm{C}$ and salinity $<34.90$, was detected at all stations between 45 and $65^{\circ} \mathrm{N}$. A local moderate oxygen minimum (ca. 30\% less than in overlaying and underlaying water) was found between ca. 200 and $700 \mathrm{~m}$ depth in the southern part of the transect (from $40-50^{\circ} \mathrm{N}$ ). Data were only used when these water masses could be clearly identified.

\subsection{VA and PA in different water masses; depth relationships}

The distribution of PA is shown in Fig. 2. PA decreased with depth by ca. an order of magnitude (Table 2), and this decrease was exponential (Reinthaler et al. 2006). The various deepwater masses exhibited some differences in PA. PA was highest in the SSL (>100 m depth), 
intermediate in the oxygen minimum zone and lowest in the bathypelagic water masses. These differences were significant (Kruskal-Wallis and Mann-Whitney tests, $\mathrm{p}<0.05$; Table 2).

VA (Fig. 2) showed a local maximum in the oxygen minimum zone at ca. $54^{\circ} \mathrm{N}, 47^{\circ} \mathrm{W}$ (ca. $500 \mathrm{~m}$ water depth) and was slightly higher close to the GIN Sea. VA decreased significantly with depth (Table 3) and was, on average, highest in the SSL $\left(3.1 \pm 1.8 \times 10^{9} 1^{-1}\right)$ and oxygen minimum zone $\left(2.7 \pm 2.9 \times 10^{9} 1^{-1}\right)$ and lowest in the NADW $\left(1.2 \pm 0.9 \times 1091^{-1}\right)$ (Table 2). Significant differences were found between the SSL and the NADW/DSOW (Kruskal-Wallis and MannWhitney tests, $\mathrm{p}<0.05$ ); however, differences between depth layers were less pronounced than for PA and were a maximum of 3.3-fold. The VPR also showed a local maximum in the oxygen minimum zone at $47.6^{\circ} \mathrm{W}, 53.5^{\circ} \mathrm{W}$ and was also highest towards the GIN Sea. In addition, VPR increased significantly with depth (Table 3). VPR was lowest in the SSL and highest in the DSOW; VPR was significantly lower in the SSL than in bathypelagic waters (Kruskal-Wallis and MannWhitney tests, $\mathrm{p}<0.05$; Table 2).

There was a tendency that $\% \mathrm{~V} 3$ (the viral subgroup with the highest fluorescence) was highest in surface water, whereas \%V1 was lower and \%V2 was higher in the bathypelagic ocean than in surface water ( $1 g^{\circ}$, 3, Table 2). A local maximum of $\% \mathrm{~V} 1$ and a local minimum of $\% \mathrm{~V} 2$ and $\% \mathrm{~V} 3$ was found at the oxygen minimum at $47.6^{\circ} \mathrm{W}, 53.5^{\circ} \mathrm{W}$. Significant differences between some water masses were found for all 3 viral flow cytometer groups (Kruskal-Wallis and Mann-Whitney tests, $\mathrm{p}<0.05$; Table 2). Significant differences with depth were only found for $\% \mathrm{~V} 1$ and $\% \mathrm{~V} 2$ (Table 3).

Co-variation of physico-chemical and biological parameters was assessed across water masses (Table 3). PA and VA increased with temperature and decreased with $\mathrm{AOU}, \mathrm{PO}_{4}$ and $\mathrm{NO}_{3}$. There were positive correlations between PA, VA and PHP.

\subsection{Viral and microbial parameters in the NADW}

In order to assess potential changes of parameters with the formation and ageing of the NADW, the distance of stations from the GIN Sea was calculated as a proxy for the length of the NADW (Fig. 1). Temperature and salinity increased significantly with distance from the GIN Sea. $\mathrm{PO}_{4}$ and $\mathrm{NO}_{3}$ concentrations increased also with distance. Oxygen concentrations decreased significantly with distance, whereas AOU increased (Table 4 ). VA and VPR decreased significantly with distance, but in a non-linear way (see also Fig. 3). The \%V1 increased (from the 2 stations closest to the GIN Sea) and V2 decreased significantly with distance (Table 4, Fig. 3).

BS was assessed at Stns 1, 13 and 31, averaging $28 \pm 5$ (range: 24-33 for the 3 samples) after correction to BSmax. For VP measurements, VA in the incubations was reduced by $77 \pm 13 \%$ 
compared to in situ VA, whereas PA was $69 \pm 16 \%$ of in situ abundance. VP averaged $0.95 \pm 0.78$ $\times 10^{4}$ viruses $1^{-1} \mathrm{~d}^{-1}$ (Table 5). FIC averaged $14 \pm 7 \%$, mean VMMPVP was $59 \pm 52 \%$ and VMMPFIC $20 \pm 12 \%$. VPi averaged $1.7 \pm 1.4 \times 10^{7}$ viruses $1^{-1} \mathrm{~d}^{-1}$, while FLC averaged $21 \pm 14 \%$. VP and FIC decreased with distance from the GIN Sea, whereas for VPi and FLC no significant relationship was found ( $\mathbb{R} i g .4)$.

Co-variation of parameters was also assessed within the NADW (Table 4). PA was positively related to oxygen concentration and negatively related to salinity and AOU. VA was negatively related to $\mathrm{AOU}, \mathrm{PO}_{4}$ and $\mathrm{NO}_{3}$ concentrations and positively to oxygen.

\section{DISCUSSION}

The data presented here indicate that different water masses maintain specific viral characteristics during their early lateral flow in the oceanic conveyor belt. Nevertheless, for the NADW, successional changes with distance from the origin could be observed for VA, subgroups, infection and lytic production.

\subsection{Depth distribution of viruses}

The decrease of VA with depth during early formation of the NADW was much less pronounced than for PA (Fig. 1, Table 2). Similar trends were found for the Atlantic (Parada et al. 2007, De Corte et al. 2010, 2012, 2016, Muck et al. 2014, Winter et al. 2018) and the Pacific (Li et al. 2014, Yang et al. 2014). Vertical transport of sinking particles is probably not always responsible for the high VPRs in the dark ocean as previously suggested (Hara et al. 1996), since very high VPRs were found in bathypelagic areas where sinking particle fluxes are generally low (Yang et al. 2014). However, since viruses can enhance aggregate formation and export into the dark ocean (i.e. viral shuttle; Peduzzi \& Weinbauer 1993, Sullivan et al. 2017, Yamada et al. 2018, Boeuf et al. 2019), viral lysis can also contribute to the sinking of viruses attached to aggregates.

Among the main causes for viral decay in the absence of sunlight are high temperatures, high molecular weight DOM and microscopic (inorganic) particles (Suttle \& Chen 1992, Cottrell \& Suttle 1995, Noble \& Fuhrman 1997). One of the obvious reasons for the high abundances of viruses in bathypelagic waters could be low decay due to low temperatures (Parada et al. 2007). This is supported by the finding that the VPR was lower and water temperature ca. $13^{\circ} \mathrm{C}$ higher in the bathypelagic zone of the Mediterranean Sea (Magagnini et al. 2007, Winter et al. 2009) than in the Atlantic Ocean.

While the low DOM concentrations in the dark ocean (e.g. Arístegui et al. 2009) likely mean reduced decay, large microscopic particles are plentiful (Bochdansky et al. 2010, 2016, Boeuf et al. 
2019) and could thus be a significant cause of viral decay. However, since there is evidence that organic particles (marine snow) are viral factories rather than viral traps (Weinbauer et al. 2009a, Bettarel et al. 2016), the particles in the dark ocean could protect viruses against decay and even foster VP. If the emerging notion holds that deep-sea prokaryotes are preferentially particleattached (e.g. DeLong et al. 2006, Baltar et al. 2009, Swan et al. 2011), these particles might be hotspots of viral infection by increasing contact rates and, hence, abundance (De Corte et al. 2012).

It has often been assumed that there is a trade-off for prokaryotes between competition for nutrients and resistance against viral infection (Thingstad 2000, Winter et al. 2010). From a fitness perspective (Thingstad et al. 2014, Thingstad \& Våge 2019), one could argue that - as the supply with organic material is low in the deep-sea (Arístegui et al. 2009)_favouring DOM uptake abilities should occur at the expense of defence against viral infection. This should result in higher VP, especially when contact rates remain high in cases where the viruses and microbes are mainly particle-attached (see paragraph above), and thus in a high VPR in the deep-sea.

There is no simple relationship between fluorescence intensity and genome size of viruses. However, as viruses do not have their own metabolism, the staining intensity with dyes such as SYBR Green does not vary for specific types of viruses. Therefore, changes in the relative proportion of viral subgroups indicate changes of viral community composition (Brussaard et al. 2010). Consequently, the variation of the viral subgroups between depth layers (Table 2) suggests differences in viral community composition. Such differences between viral subgroups have also been found in other studies (De Corte et al. 2010, Muck et al. 2014) and were confirmed by using pulsed-field gel electrophoresis (Parada et al. 2007), randomly amplified polymorphic DNA-PCR (RAPD-PCR; De Corte et al. 2010, Winter \& Weinbauer 2010, Muck et al. 2014) and metagenomics (Mizuno et al. 2016, Winter et al. 2018, Gregory et al. 2019, Liang et al. 2019). Using viral subgroups, the strongest differences were found between the SSL and bathypelagic water masses, suggesting that specific viral communities are inhabiting these environments. A likely reason for the differences in viral community composition is differences in host activity and community structure diversity in these water masses as assessed during the same cruise (Teira et al. 2004, Reinthaler et al. 2006).

\subsection{Lysogeny in the NADW}

FLC in the NADW data ranged from 4.5-40.1\%, which is similar to another study from the deep ocean using the VRA approach (10.1-27.3\%; Muck et al. 2014). Using a whole seawater approach, FLC values were found to be highest in the bathypelagic zone of the Mediterranean Sea 
(73.2\%; Weinbauer et al. 2003). Using the VRA approach, FLC values from the NADW were higher than FIC values (Fig. 4, Table 5).

FLC and lysogenic VP did not vary significantly with distance from the GIN Sea (Fig. 4b,d, Table 5). Also, FLC and lysogenic VP did not vary significantly with PHP (Spearman rank correlation, $\rho<0.65, p>0.15)$. In other studies of the Atlantic Ocean, inducible VP did not change (or changed little) with depth from the epipelagic to the abyssopelagic zone, whereas PA, PHP and lytic VP decreased strongly with depth (De Corte et al. 2010, 2012, Muck et al. 2014).

Metagenomic data indicate that lysogeny is the predominant life strategy in the deep ocean (Williamson et al. 2008, Mizuno et al. 2016). Thus, these data support the general idea that lysogeny dominates when the encounter rate between phages and host cells is low (Stewart \& Levin 1984, Weinbauer et al. 2003, Weinbauer 2004). However, in the Malaspina Circumnavigation Experiment, Lara et al. (2017) found that lysogeny dominated in surface water and lytic VP became more important in deep water, hence supporting both hypotheses, i.e. promotion of lysogeny by low growth rates and low nutrient conditions ('classic' explanation) and promotion at high host abundance ('piggyback-the-winner' model) (Knowles et al. 2016). This indicates that the lyticlysogenic switch is likely more complex than previously thought, which calls for further studies (Lara et al. 2017). Independent of the lytic-lysogeny switch argument, all studies show that lysogeny is significant in the deep sea. It has been hypothesized that marine prophages directly contribute to host survival in unfavourable environments by suppressing superfluous metabolic activities (Paul 2008), which could be particularly important in the carbon-limited dark ocean.

\subsection{VA and infection during the formation of the NADW}

VA, VPR, lytic VP and FIC decreased with distance from the GIN sea. Among the factors which could have influenced these parameters during the early formation of the NADW are (1) physical factors (temperature or mixing of the NADW with adjacent water masses), (2) sinking of particles from surface water into the interior of the ocean (export of viruses or stimulation of host activity) and (3) successional (i.e. internal temporal changes such as changes in community composition or resistance).

VA decreased in the NADW and temperature increased with distance from its formation (Fig. 3, Table 4). It is possible that the ca. $50 \mathrm{yr}$ transport into warming water resulted in an increased decay and contributed to losses of viruses. The increase in temperature and salinity in the NADW with distance from its formation (Table 4) is caused by mixing with adjacent water masses such as the overlying LSW, which is warmer and lower in salinity than the NADW (van Aken 2000a,b). Since VA was higher in the LSW than in the NADW, one would expect VA to increase 
with distance in the NADW; however, they decreased, instead indicating that other factors were more important than direct mixing processes. Mixing of deep sea water masses can cause an increase in prokaryotic production and hence VP (Muck et al. 2014) e.g. by induction of lysogens (Winter et al. 2018). Our data set did not allow us to evaluate this possibility for the NADW.

General distribution patterns of chlorophyll $a(\mathrm{chl} a)$ during the TRANSAT-II cruise suggest a potentially decreasing sinking particle flux and thus a potentially decreasing viral export flux with distance from the GIN Sea (Teira et al. 2004, Reinthaler et al. 2006). If sinking particles are a source of viruses for the dark ocean, such a pattern could contribute to the finding of a decrease in VA and VPR with age of the NADW (but see discussion on transport of viruses on particles in Section 4.1). Release of viruses from sinking particles could for example explain local maxima of viral parameters as detected in this study (Fig. 2). The decrease of VA, VPR, VP and FIC with distance from the GIN Sea was not accompanied by a change in PA and PHP (Table 4). Thus, there is no support for the hypothesis that sinking aggregates (transporting viruses and prokaryotes) or the supply of organic matter into the NADW caused the observed viral (and prokaryotic) patterns with distance from the GIN Sea.

Assuming a conservative prokaryotic turnover time of ca. 1 mo in the NADW (Reinthaler et al. 2006) and an investigated time frame for the formation of the NADW of $50 \mathrm{yr}$, prokaryotes produced ca. 600 generations of offspring. Correlation analysis indicates that (micro)organisms consume oxygen and remineralize $\mathrm{PO}_{4}$ and $\mathrm{NO}_{3}$ during this transport (Table 4). It is possible that prokaryotic community composition changed during these 600 generations. Changes in community composition of hosts can affect the community composition of virioplankton (e.g. Winter et al. 2010). Such a mechanism could explain the finding that viral community composition, as indicated by the relative abundance of viral groups, changed significantly with age of the NADW. Since the BS of viruses is quite variable (Børsheim 1993), changes in the community composition to virushost systems with lower BSs could contribute to the decrease of VA and VPR with distance from the GIN Sea. The few data on BS support this idea (Table 5).

In a 2 yr pressure incubation (corresponding to pressure at $3000 \mathrm{~m}$ water depth) with various phage isolates and a natural virus community, it was found that small and low fluorescence viruses decayed slower than larger or high fluorescence viruses (Tian et al 2020). The finding that the proportion of the V1 group (low fluorescence) became more important with distance from the GIN Sea compared to V2 and V3 groups (higher fluorescence) (Fig. 3b,c) could therefore be explained by lower decay rates. Thus, variable decay rates between different types of viruses could change the virus community and hence infection patterns. 
Resistance against infection is a well known phenomenon from studies with isolates (Avrani et al. 2012). Among the more recently detected resistance mechanisms is CRISPR (Barrangou et al. 2007). CRISPR is a sort of immune system for prokaryotes in the sense that it confers resistance to bacterial and archaea cells against mobile genetic elements such as viruses (e.g. Barrangou et al. 2007, Vestergaard et al. 2008). Exposure of prokaryotes to viruses for 600 generations and development of resistance is therefore another possible cause for the decrease of VA and lytic infection with ageing NADW. If the resistance hypothesis holds, viral types belonging to the V2 group would be the loser in the arms-race with prokaryotic hosts compared to type V1, which decrease in relative abundance with distance from the GIN Sea.

Applying the reasoning of a fitness penalty in a low-nutrient environment (see Section 4.1), it can be argued that the fitness costs of resistance should increase with distance from the GIN Sea, i.e. with the ageing of NADW. Hence, a strategy towards competitive traits with high susceptibility to viral infection could be anticipated. However, there is no evidence that viral infection or VPR increased; on the contrary, these parameters decreased with distance from the GIN Sea. Overall, VPR was very high at the origin of the GIN Sea, and despite the decline with ageing of the NADW it remained higher than in surface water. It is possible that the high VPR values in origin water masked fitness-related trends. In this context, it is important to mention that temperature increased in the NADW with distance from the GIN Sea. Alternatively, the origin water could have been already characterized by conditions favouring competitive over defence traits.

\subsection{VP, mortality and carbon release in the NADW}

Lytic VP ranged from $2.2-2.5 \times 10^{7} 1^{-1} \mathrm{~d}^{-1}$. These values are slightly lower than the lytic VP estimated in other bathy- and abyssopelagic environments $\left(3.6 \times 17-8.4 \times 10^{9} 1^{-1} \mathrm{~d}^{-1}\right.$ (De Corte et al. 2010 2012, Umani et al. 2010, Li et al. 2014, Muck et al. 2016, Lara et al. 2017, Winter et al. 2018). The FIC (0.6-22.0\%) was at the lower range compared to other studies (15-143\%; Muck et al. 2014, Winter et al. 2018).

Using 2 different methods for estimating the role of viral lysis for prokaryotic mortality, estimates based on VMMPVP were on average 2.7 higher than estimates based on VMMPFIC (Table 5). It is a well known but poorly understood phenomenon that different methods for estimating VMMP are not always fully congruent (Winter et al. 2004, Helton et al. 2005, Winget et al. 2005, Weinbauer et al. 2009b). Nevertheless, data from both methods suggest significant mortality due to viral lysis in the NADW (on average $20 \%$ by VMMPFIC and $59 \%$ by VMMPVP, respectively). Finally, viruses have been detected within cells (Weinbauer et al. 2003, this study). This finding supports that of $\mathrm{Li}$ et al. (2014) that there is an autochthonous active virus community in the deep 
sea. Also, endemic deep-sea virus communities have been documented by metagenomics (Winter et al. 2014, 2018, Mizuno et al. 2016, Gregory et al. 2019, Liang et al. 2019).

Using a conversion factor of $12.4 \mathrm{fg} \mathrm{cell}^{-1}$ for the dark ocean (Fukuda et al. 1998) and data from Table 5, the carbon release by viral lysis of prokaryotes would be $8.6 \pm 5.5 \mathrm{ng} \mathrm{C} \mathrm{l}^{-1} \mathrm{~d}^{-1}$ using VMMPVP $_{\text {and }} 2.9 \pm 1.4 \mathrm{ng} \mathrm{C}^{-1} \mathrm{~d}^{-1}$ using VMMPFIC. This is lower than the $0.03-0.69 \mu \mathrm{g} \mathrm{C}^{-1} \mathrm{~d}^{-1}$ estimated by Li et al. (2014). The majority of DOM in the deep sea is characterized by low turnover times and is either too recalcitrant or too diluted to be used by prokaryotes (Jiao et al. 2011, Arrieta et al. 2015). Viral lysis products consist of cell contents and wall cell debris such as DNA, RNA, carbohydrates, amino acids, glucosamine and diaminopimelic acid (Weinbauer et al. 1993, Weinbauer \& Peduzzi 1995, Middelboe \& Jorgensen 2006) and are rapidly degraded, hence belonging to the pool of labile DOM (Noble \& Fuhrman 1999, Middelboe \& Lyck 2002). This may relieve the carbon limitation of the growth of deep-sea prokaryotes. Also, organic matter from cells shunted into the DOM pool by viral lysis is hardly accessible to higher trophic levels, thus resulting in a slower transfer of organic matter towards higher trophic levels (Fuhrman 1999). This process could sustain a high prokaryotic biomass and provide an important contribution to prokaryotic metabolism, allowing the system to cope with the severe organic resource limitation of deep-sea ecosystems as has been demonstrated for benthic and pelagic communities (Danovaro et al. 2008, Lara et al. 2017). Moreover, viral lysis may prime the biological pump and the microbial carbon pump and hence carbon sequestration in the ocean, which has significant global consequences (Suttle 2007, Brussaard et al. 2008, Jiao et al. 2011, Guidi et al. 2016).

Acknowledgements. We thank the captain and crew of the R/V 'Pelagia' for their support at sea, and K. Bakker, J. Hegeman, S. Gonzalez and A. Smit for help during sample processing. The comments of 2 reviewers improved a former version of the manuscript. This work was supported by a grant of the Dutch Science Foundation Earth and Life Sciences (NWO-ALW, project \# 811.33.004) to G.J.H and the French Science Ministry (ANR grant AQUAPHAGE) to M.G.H.

\section{LITERATURE CITED}

<jrn>Agogué H, Lamy D, Neal PR, Sogin ML, Herndl GJ (2011) Water mass-specificity of bacterial communities in the North Atlantic revealed by massively parallel sequencing. Mol Ecol 20:258-274 PubMed doi:10.1111/j.1365-294X.2010.04932.x $</$ jrn $>$

$<$ jrn>Arístegui J, Gasol JM, Duarte CM, Herndl GJ (2009) Microbial oceanography of the dark ocean's pelagic realm. Limnol Oceanogr 54:1501-1529 doi:10.4319/10.2009.54.5.1501</jrn> 
$<$ jrn>Arrieta JM, Mayol E, Hansman RL, Herndl GJ, Dittmar T, Duarte CM (2015) Dilution limits dissolved organic carbon utilization in the deep ocean. Science 348:331-333 PubMed doi:10.1126/science. $1258955</$ jrn $>$

$<$ jrn>Avrani S, Schwartz DA, Lindell D (2012) Virus-host swinging party in the oceans: incorporating biological complexity into paradigms of antagonistic coexistence. Mob Genet Elements 2:88-95 PubMed doi:10.4161/mge.20031</jrn>

$<$ jrn>Baltar F, Arístegui J, Gasol JM, Sintes E, Herndl GJ (2009) Evidence of prokaryotic metabolism on suspended particulate organic matter in the dark waters of the subtropical North Atlantic. Limnol Oceanogr 54:182-193 doi:10.4319/lo.2009.54.1.0182</jrn>

$<$ jrn $>$ Barrangou R, Fremaux C, Deveau H, Richards M and others (2007) CRISPR provides acquired resistance against viruses in prokaryotes. Science 315:1709-1712 PubMed doi: $10.1126 /$ science. $1138140</ \mathrm{jrn}>$

$<$ jrn>Bettarel Y, Motegi C, Weinbauer MG, Mari X (2016) Colonization and release processes of viruses and prokaryotes on artificial marine macroaggregates. FEMS Microbiol Lett 363:fnv216 $\underline{\text { PubMed doi:10.1093/femsle/fnv216 }}</$ jrn $>$

$<$ jrn $>$ Binder B (1999) Reconsidering the relationship between virally induced bacterial mortality and frequency of infected cells. Aquat Microb Ecol 18:207-215 doi:10.3354/ame018207</jrn>

$<$ jrn> Bochdansky AB, van Aken HM, Herndl GJ (2010) Role of macroscopic particles in deep-sea oxygen consumption. Proc Natl Acad Sci USA 107:8287-8291 PubMed doi:10.1073/pnas.0913744107 $</$ jrn $>$

$<$ jrn>Bochdansky AB, Clouse MA, Herndl GJ (2016) Dragon kings of the deep sea: Marine particles deviate markedly from the common number-size spectrum. Sci Rep 6:22633 PubMed doi: $10.1038 /$ srep22633 $</ j r n>$

$<$ jrn>Boeuf D, Edwards BR, Eppley JM, Hu SK and others (2019) Biological composition and microbial dynamics of sinking particulate organic matter at abyssal depths in the oligotrophic open ocean. Proc Natl Acad Sci USA 116:11824-11832 PubMed $<$ jrn>

$<$ jrn>Bohannan BJM, Lenski RE (1997) Effect of resource enrichment on a chemostat community of bacteria and bacteriophage. Ecology 78:2303-2315 doi:10.1890/00129658(1997)078[2303:EOREOA]2.0.CO;2</jrn $>$

$<$ jrn>Børsheim KY (1993) Native marine bacteriophages. FEMS Microbiol Ecol 102:141-159 doi:10.1016/0378-1097(93)90197-A $<$ jrn $>$ 
$<$ jrn>Broecker WS (1997) Thermohaline circulation, the Achilles heel of our climate system: Will man-made $\mathrm{CO}_{2}$ upset the current balance? Science 278:1582-1588 PubMed doi:10.1126/science. $278.5343 .1582</$ jrn $>$

$<$ jrn>Brussaard CPD, Wilhelm SW, Thingstad F, Weinbauer MG and others (2008) Global-scale processes with a nanoscale drive: the role of marine viruses. ISME J 2:575-578 PubMed doi:10.1038/ismej.2008.31</jrn $>$

$<$ edb $>$ Brussaard CPD, Payet JP, Winter C, Weinbauer MG (2010) Quantification of aquatic viruses by flow cytometry. In: Wilhelm SW, Weinbauer MG, Suttle C (eds) Manual of aquatic viral ecology. American Society of Limnology and Oceanography, Waco, TX, p 102-109</edb>

$<$ jrn $>$ Cottrell MT, Suttle CA (1995) Dynamics of a lytic virus infecting the photosynthetic marine picoflagellate Micromonas pusilla. Limnol Oceanogr 40:730-739 doi:10.4319/lo.1995.40.4.0730</jrn>

$<$ jrn>Danovaro R, Dell'Anno A, Corinaldesi C, Magagnini M, Noble R, Tamburin C, Weinbauer MG (2008) Major viral impact on the functioning of benthic deep-sea ecosystems. Nature 454:1084-1087 PubMed doi:10.1038/nature07268 $<$ jirn $>$

$<$ jrn $>$ De Corte D, Sintes E, Winter C, Yokokawa T, Reinthaler T, Herndl GJ (2010) Links between viral and prokaryotic communities throughout the water column in the (sub)tropical Atlantic Ocean. ISME J 4:1431-1442 PubMed doi:10.1038/ismej.2010.65</jrn>

$<$ jrn $>$ De Corte D, Sintes E, Yokokawa T, Reinthaler T, Herndl GJ (2012) Links between viruses and prokaryotes throughout the water column along a North Atlantic latitudinal transect. ISME $\mathbf{J}$ 6:1566-1577 PubMed doi:10.1038/ismej.2011.214</jrn>

$<$ jrn $>$ De Corte D, Sintes E, Yokokawa T, Lekunberri I, Herndl GJ (2016) Large-scale distribution of microbial and viral populations in the South Atlantic Ocean. Environ Microbiol Rep 8:305315 PubMed doi:10.1111/1758-2229.12381 </jrn>

$<$ jrn $>$ DeLong EF, Preston CM, Mincer T, Rich V and others (2006) Community genomics among stratified microbial assemblages in the ocean's interior. Science 311:496-503 PubMed doi:10.1126/science. $1120250</$ jrn $>$

$<$ jrn>Fuhrman JA (1999) Marine viruses and their biogeochemical and ecological effects. Nature 399:541-548 PubMed doi:10.1038/21119 $<$ /jrn>

$<$ jrn $>$ Fukuda R, Ogawa H, Nagata T, Koike I (1998) Direct determination of carbon and nitrogen contents of natural bacterial assemblages in marine environments. Appl Environ Microbiol 64:3352-3358 PubMed doi:10.1128/AEM.64.9.3352-3358.1998</jrn> 
$<$ jrn $>$ Gobler CJ, Hutchins DA, Fisher NS, Cosper EM, Sañudo-Wilhelmy SA (1997) Release and bioavailability of C, N, P, Se and Fe following viral lysis of a marine chrysophyte. Limnol Oceanogr 42:1492-1504 doi:10.4319/lo.1997.42.7.1492</jrn>

$<$ jrn $>$ Gregory AC, Zayed AA, Conceicao-Neto N, Temperton B and others (2019) Marine DNA viral macro- and microdiversity from pole to pole. Cell 177:1109-1123 PubMed doi:10.1016/j.cell.2019.03.040 $</$ jrn $>$

$<$ jrn> Guidi L, Chaffron S, Bittner L, Eveillard D and others (2016) Plankton networks driving carbon export in the oligotrophic ocean. Nature 532:465-470 PubMed doi:10.1038/nature16942</jrn $>$

$<$ jrn>Hara S, Koike I, Terauchi K, Kamiya H, Tanoue E (1996) Abundance of viruses in deep oceanic waters. Mar Ecol Prog Ser 145:269-277 doi:10.3354/meps145269</jrn>

$<$ jrn $>$ Helton RR, Cottrell MT, Kirchman DL, Wommack KE (2005) Evaluation of incubation-based methods for estimating virioplankton production in estuaries. Aquat Microb Ecol 41:209-219 doi:10.3354/ame041209 $<$ jirn $>$

$<$ jrn $>$ Jiao N, Herndl GJ, Hansell DA, Benner R and others (2011) The microbial carbon pump and the oceanic recalcitrant dissolved organic matter pool. Nat Rev Microbiol 9:555 doi: $10.1038 /$ nrmicro2386-c5 $</$ jrn $>$

$<$ jrn $>$ Knowles B, Silveira CB, Bailey BA, Barott K and others (2016) Lytic to temperate switching of viral communities. Nature 531:466-470 PubMed doi:10.1038/nature17193 </jrn>

$<$ jrn> Lara E, Vaqué D, Sà EL, Boras JA and others (2017) Unveiling the role and life strategies of viruses from the surface to the dark ocean. Sci Adv 3:e1602565 PubMed doi:10.1126/sciadv.1602565 $<$ jrn $>$

$<$ jrn>Li Y, Luo T, Sun J, Cai L, Liang Y, Jiao N, Zhang R (2014) Lytic viral infection of bacterioplankton in deep waters of the Western Pacific Ocean. Biogeosciences 11:2531-2542 doi:10.5194/bg-11-2531-2014</jrn>

$<$ jrn> Liang Y, Wang L, Wang Z, Zhao J and others (2019) Metagenomic analysis of the diversity of DNA viruses in the surface and deep sea of the South China Sea. Front Microbiol 10:1951 $\underline{\text { PubMed doi:10.3389/fmicb.2019.01951 }</ \text { jrn }>}$

$<$ jrn>Middelboe M, Jorgensen NOG (2006) Viral lysis of bacteria: an important source of dissolved amino acids and cell wall compounds. J Mar Biol Assoc UK 86:605-612 doi:10.1017/S0025315406013518</jrn $>$ 
$<$ jrn>Middelboe M, Lyck PG (2002) Regeneration of dissolved organic matter by viral lysis in marine microbial communities. Aquat Microb Ecol 27:187-194 doi:10.3354/ame027187</jrn>

$<$ jrn>Mizuno CM, Ghai R, Saghai A, Lopez-Garcia P, Rodriguez-Valera F (2016) Genomes of abundant and widespread viruses from the deep ocean. MBio 7:e00805-16 $\underline{\text { PubMed }}$ doi:10.1128/mBio.00805-16 $</ j r n>$

$<$ jrn>Muck S, Griessler T, Köstner N, Klimiuk A, Winter C, Herndl GJ (2014) Fracture zones in the Mid Atlantic Ridge lead to alterations in prokaryotic and viral parameters in deep-water masses. Front Microbiol 5:264 PubMed doi:10.3389/fmicb.2014.00264</jrn>

$<$ jrn>Murray AG, Jackson GA (1992) Viral dynamics: a model of the effects of size, shape, motion and abundance of single-celled planktonic organisms and other particles. Mar Ecol Prog Ser 89:103-116 doi:10.3354/meps089103 $<$ jrn $>$

$<$ jrn $>$ Nagata T, Fukuda H, Fukuda R, Koike I (2000) Bacterioplankton distribution and production in deep Pacific waters: large-scale geographic variations and possible coupling with sinking particle fluxes. Limnol Oceanogr 45:426-435 doi:10.4319/lo.2000.45.2.0426</jrn>

$<$ jrn $>$ Noble RT, Fuhrman JA (1997) Virus decay and its causes in coastal waters. Appl Environ Microbiol 63:77-83 PubMed doi:10.1128/AEM.63.1.77-83.1997</jrn>

$<$ jrn $>$ Noble RT, Fuhrman JA (1999) Breakdown and microbial uptake of marine viruses and other lysis products. Aquat Microb Ecol 20:1-11 doi:10.3354/ame020001</jrn>

$<$ jrn>Parada V, Herndl GJ, Weinbauer MG (2006) Viral burst size of heterotrophic prokaryotes in aquatic systems. J Mar Biol Assoc UK 86:613-621 doi:10.1017/S002531540601352X_/jrn>

$<$ jrn $>$ Parada V, Sintes E, van Aken HM, Weinbauer MG, Herndl GJ (2007) Viral abundance, decay and diversity in the meso- and bathypelagic waters of the North Atlantic. Appl Environ Microbiol 73:4429-4438 PubMed doi:10.1128/AEM.00029-07</jrn>

$<$ jrn $>$ Paul JH (2008) Prophages in marine bacteria: Dangerous molecular time bombes or key to the survival in the seas? ISME J 2:579-589 PubMed doi:10.1038/ismej.2008.35 </jrn>

$<$ edb $>$ Paul JH, Weinbauer MG (2010) Detection of lysogeny in marine environments. In: Wilhelm SW, Weinbauer MG, Suttle C (eds) Manual of aquatic viral ecology. American Society of Limnology and Oceanography, Waco, TX, p 30-33</edb $>$

$<$ jrn>Peduzzi P, Weinbauer MG (1993) Effect of concentrating the virus-rich 2-200 nm size fraction of seawater on the formation of algal flocs (marine snow). Limnol Oceanogr 38:15621565 doi:10.4319/10.1993.38.7.1562</jrn> 
$<$ jrn $>$ Reinthaler T, van Aken H, Veth C, Arístegui J, Robinson C, Williams PJL (2006) Prokaryotic respiration and production in the meso-and bathypelagic realm of the eastern and western North Atlantic basin. Limnol Oceanogr 51:1262-1273 doi:10.4319/lo.2006.51.3.1262</jrn>

$<$ jrn $>$ Steward GF, Smith DC, Azam F (1996) Abundance and production of bacteria and viruses in the Bering and Chukchi Seas. Mar Ecol Prog Ser 131:287-300 doi:10.3354/meps131287</jrn> $<$ jrn>Stewart FM, Levin BR (1984) The population biology of bacterial viruses: why be temperate. Theor Popul Biol 26:93-117 PubMed doi:10.1016/0040-5809(84)90026-1</jrn>

$<$ jrn $>$ Sullivan MB, Weitz JS, Wilhelm S (2017) Viral ecology comes of age. Environ Microbiol Rep 9:33-35 PubMed doi:10.1111/1758-2229.12504</jrn>

$<$ jrn $>$ Suttle CA (2007) Marine viruses - major players in the global ecosystem. Nat Rev Microbiol 5:801-812 PubMed doi:10.1038/nrmicro1750 $<$ jrn $>$

$<$ jrn $>$ Suttle CA, Chen F (1992) Mechanisms and rates of decay of marine viruses in seawater. Appl Environ Microbiol 58:3721-3729 PubMed doi:10.1128/AEM.58.11.3721-3729.1992</jrn>

$<$ jrn>Swan BK, Martinez-Garcia M, Preston CM, Sczyrba A and others (2011) Potential for chemolithoautotrophy among ubiquitous bacteria lineages in the dark ocean. Science 333:12961300 PubMed doi:10.1126/science. $1203690</$ jrn $>$

$<$ jrn>Teira E, Reinthaler T, Pernthaler A, Pernthaler J, Herndl GJ (2004) Combining catalyzed reporter deposition-fluorescence in situ hybridization and microautoradiography to detect substrate utilization by Bacteria and Archaea in the deep ocean. Appl Environ Microbiol 70:4411-4414 PubMed doi:10.1128/AEM.70.7.4411-4414.2004</jrn>

$<$ jrn> Teira E, Lebaron P, van Aken H, Herndl GJ (2006) Distribution and activity of Bacteria and Archaea in the deep water masses of the North Atlantic. Limnol Oceanogr 51:2131-2144 doi:10.4319/10.2006.51.5.2131</jrn $>$

$<$ jrn> Thingstad TF, Våge S (2019) Host-virus-predator coexistence in a grey-box model with dynamic optimization of host fitness. ISME J 13:3102-3111 PubMed doi:10.1038/s41396-019$\underline{0496-7}</ \mathrm{jrn}>$

$<$ jrn>Thingstad TF, Våge S, Storesund JE, Sandaa RA, Giske J (2014) A theoretical analysis of how strain-specific viruses can control microbial species diversity. Proc Natl Acad Sci USA 111:7813-7818 PubMed doi:10.1073/pnas.1400909111</jrn>

Tian Y, Cai L, Xu Y, Luo T and others (2020) Stability and infectivity of allochthonous viruses in deep sea: A long-term high pressure simulation experiment. 
$<$ jrn $>$ Umani SF, Malisana E, Focaracci F, Magagnini M, Corinaldesi C, Danovaro R (2010)

Disentangling the effect of viruses and nanoflagellates on prokaryotes in bathypelagic waters of the Mediterranean Sea. Mar Ecol Prog Ser 418:73-85 doi:10.3354/meps08803</jrn>

$<$ jrn>Våge S, Bratbak G, Egge J, Heldal M and others (2018) Simple models combining

competition, defence and resource availability have broad implications in pelagic microbial food webs. Ecol Lett 21:1440-1452 PubMed doi:10.1111/ele.13122</jrn $>$

$<$ jrn $>$ van Aken HM (2000a) The hydrography of the mid-latitude Northeast Atlantic Ocean. I: the deep water masses. Deep Sea Res I 47:757-788 doi:10.1016/S0967-0637(99)00092-8</jrn>

$<$ jrn> van Aken HM (2000b) The hydrography of the mid-latitude Northeast Atlantic Ocean. II: the intermediate water masses. Deep Sea Res I 47:789-824 doi:10.1016/S0967-0637(99)00112$\underline{0}</ \mathrm{jrn}>$

$<$ jrn $>$ Vestergaard G, Shah SA, Bize A, Reitberger W and others (2008) Stygiolobus rod-shaped virus and the interplay of crenarchaeal rudiviruses with the CRISPR antiviral system. J Bacteriol 190:6837-6845 PubMed doi:10.1128/JB.00795-08< $<$ jrn $>$

$<$ jrn $>$ Weinbauer MG (2004) Ecology of prokaryotic viruses. FEMS Microbiol Rev 28:127-181

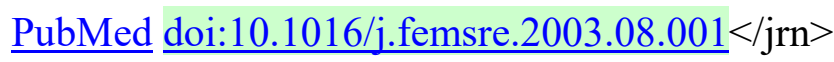

$<$ jrn> Weinbauer MG, Peduzzi P (1995) Effect of virus-rich high molecular weight concentrates of seawater on the dynamics of dissolved amino acids and carbohydrates. Mar Ecol Prog Ser 127:245-253 doi:10.3354/meps127245 </jrn>

$<$ jrn $>$ Weinbauer MG, Suttle CA (1999) Lysogeny and prophage induction in coastal and offshore bacterial communities. Aquat Microb Ecol 18:217-225 doi:10.3354/ame018217</jrn>

$<$ jrn> Weinbauer MG, Fuks D, Peduzzi P (1993) Distribution of viruses and dissolved DNA along a coastal trophic gradient in the northern Adriatic Sea. Appl Environ Microbiol 59:4074-4082

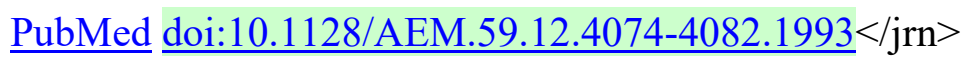

$<$ jrn>Weinbauer MG, Winter C, Höfle MG (2002) Reconsidering transmission electron microscopy based estimates of viral infection of bacterioplankton using conversion factors derived from natural communities. Aquat Microb Ecol 27:103-110 doi:10.3354/ame027103</jrn>

$<$ jrn> Weinbauer MG, Brettar I, Höfle MG (2003) Lysogeny and virus-induced mortality of bacterioplankton in surface, deep, and anoxic waters. Limnol Oceanogr 48:1457-1465 doi:10.4319/10.2003.48.4.1457</jrn $>$ 
$<$ jrn>Weinbauer MG, Bettarel Y, Cattaneo R, Luef B and others (2009a) Viral ecology of organic and inorganic particles in aquatic systems: avenues for further research. Aquat Microb Ecol 57:321-341 PubMed doi:10.3354/ame01363 $</$ jrn $>$

$<$ jrn $>$ Weinbauer MG, Arrieta JM, Griebler C, Herndl GJ (2009b) Enhanced viral production and infection of bacterioplankton during an iron-induced phytoplankton bloom in the Southern Ocean. Limnol Oceanogr 54:774-784 doi:10.4319/lo.2009.54.3.0774</jrn>

$<$ edb $>$ Weinbauer MG, Rowe JM, Wilhelm SW (2010) Determining rates of virus production in aquatic systems by the virus reduction approach. In: Wilhelm SW, Weinbauer MG, Suttle C (eds) Manual of aquatic viral ecology. American Society of Limnology and Oceanography, Waco, TX, p 1-8</edb $>$

$<$ jrn $>$ Wilhelm SW, Suttle CA (1999) Viruses and nutrient cycles in the sea. BioScience 49:781-788 doi: $10.2307 / 1313569</$ jrn $>$

$<$ jrn $>$ Wilhelm SW, Brigden SM, Suttle CA (2002) A dilution technique for the direct measurement of viral production: a comparison in stratified and tidally mixed coastal waters. Microb Ecol 43:168-173 PubMed doi:10.1007/s00248-001-1021-9</jrn>

$<$ edb $>$ Williams ST (1994) Bacteriophages in soils. In: Webster RG, Granoff A (eds) Encyclopedia of virology. Academic Press, London, p 121-126</edb $>$

$<$ jrn $>$ Williamson SJ, Cary SC, Williamson KE, Helton RR, Bench SR, Winget D, Wommack KE (2008) Lysogenic virus-host interactions predominate at deep-sea diffuse-flow hydrothermal vents. ISME J 2:1112-1121 PubMed doi:10.1038/ismej.2008.73 $</$ jrn>

$<$ jrn $>$ Winget DM, Williamson KE, Helton RR, Wommack KE (2005) Tangential flow diafiltration: an improved technique for estimation of virioplankton production. Aquat Microb Ecol 41:221232 doi: $10.3354 /$ ame $041221</$ jrn $>$

$<$ jrn $>$ Winter C, Herndl GJ, Weinbauer MG (2004) Diel cycles in viral infection of bacterioplankton in the North Sea. Aquat Microb Ecol 35:207-216 doi:10.3354/ame035207</jrn>

$<$ jrn>Winter C, Kerros ME, Weinbauer MG (2009) Seasonal and depth-related dynamics of prokaryotes and viruses in surface and deep waters of the northwestern Mediterranean Sea. Deep Sea Res I 56:1972-1982 doi:10.1016/j.dsr.2009.07.003 $<$ jrn $>$

$<$ jrn $>$ Winter C, Bouvier T, Weinbauer MG, Thingstad TF (2010) Trade-offs between competition and defense specialists in unicellular planktonic organisms - the 'killing the winner' hypothesis revisited. Microbiol Mol Biol Rev 74:42-57 PubMed doi:10.1128/MMBR.00034-09</jrn> 
$<$ jrn> Winter C, Köstner N, Kruspe CP, Urban D, Muck S, Reinthaler T, Herndl GJ (2018) Mixing alters the lytic activity of viruses in the dark ocean. Ecology 99:700-713 PubMed doi:10.1002/ecy.2135</jrn>

$<$ jrn $>$ Wommack KE, Colwell RR (2000) Virioplankton: viruses in aquatic ecosystems. Microbiol Mol Biol Rev 64:69-114 PubMed doi:10.1128/MMBR.64.1.69-114.2000</jrn>

$<$ jrn $>$ Yamada Y, Tomaru Y, Fukuda H, Nagata T (2018) Aggregate formation during the viral lysis of a marine diatom. Front Mar Sci 5:167 doi:10.3389/fmars.2018.00167</jrn>

$<$ jrn $>$ Yang Y, Yokokawa T, Motegi C, Nagata T (2014) Large-scale distribution of viruses in deep waters of the Pacific and Southern Oceans. Aquat Microb Ecol 71:193-202 doi:10.3354/ame01677</jrn>

$<$ jrn $>$ Zimmerman AE, Howard-Varona C, Needham DM, John SG and others (2020) Metabolic and biogeochemical consequences of viral infection in aquatic ecosystems. Nat Rev Microbiol 18:21-34 $\underline{\text { PubMed }</ j r n>~}$ 


\begin{tabular}{|c|c|c|c|c|c|c|c|}
\hline Water mass & $\begin{array}{c}\text { No. of } \\
\text { samples }\end{array}$ & $\begin{array}{c}\text { PA } \\
\left(\times 10^{8} \text { cells } 1^{-1}\right)\end{array}$ & $\begin{array}{c}\text { VA } \\
\left(\times 10^{9} \text { particles } 1^{-1}\right) \\
\end{array}$ & $\begin{array}{l}\text { V1 } \\
(\%)\end{array}$ & $\begin{array}{l}\text { V2 } \\
(\%)\end{array}$ & $\begin{array}{l}\text { V3 } \\
(\%)\end{array}$ & VPR \\
\hline SSL & 33 & $3.58(0.94)(\mathrm{A})$ & $3.1(1.8)(\mathrm{A})$ & $73.1(4.0)(\mathrm{A})$ & $20.3(4.1)(\mathrm{A})$ & $6.5(1.5)(\mathrm{A})$ & $9.8(5.6)(\mathrm{A})$ \\
\hline $\mathrm{O}_{2}-\min$ & 15 & $1.27(0.49)(\mathrm{B})$ & $2.7(2.9)(\mathrm{A}, \mathrm{B})$ & $78.3(9.1)(\mathrm{A}, \mathrm{B})$ & $17.2(7.8)(\mathrm{A})$ & $4.5(1.6)(\mathrm{B})$ & $27.0(38.9)(\mathrm{A})$ \\
\hline LSW & 32 & $0.50(0.17)(\mathrm{C})$ & $1.5(0.8)(\mathrm{A}, \mathrm{B})$ & $66.3(7.3)(\mathrm{B}, \mathrm{C})$ & $28.8(7.5)(\mathrm{A})$ & $4.8(1.7)(\mathrm{B})$ & $32.4(21.3)(\mathrm{A})$ \\
\hline NADW & 25 & $0.30(0.06)(\mathrm{C})$ & $1.2(0.9)(\mathrm{B})$ & $69.0(5.8)(\mathrm{B}, \mathrm{C})$ & $26.4(5.1)(\mathrm{B})$ & $4.6(2.0)(\mathrm{B})$ & $40.8(26.5)(\mathrm{A}, \mathrm{B})$ \\
\hline DSOW & 22 & $0.43(0.26)(\mathrm{C})$ & $2.3(2.1)(\mathrm{B})$ & $69.2(8.1)(\mathrm{C})$ & $26.1(7.3)(\mathrm{B})$ & $4.6(1.7)(\mathrm{B})$ & $42.9(18.2)(\mathrm{B})$ \\
\hline Kruskal-Wallis (p-value) & & $<0.0001$ & $<0.0001$ & $<0.0001$ & $<0.0001$ & $<0.0001$ & $<0.0001$ \\
\hline
\end{tabular}

Table 1. Averaged water layer properties of selected physico-chemical parameters in the western North Atlantic basin. T: temperature; $\sigma_{\tau}$ : water density. SSL: subsurface layer; O2-min: oxygen minimum zone; LSW: Labrador Sea Water; NADW: North Atlantic Deep Water; DSOW: Denmark Strait Overflow Water. Values in parentheses: SD

\begin{tabular}{|lcccccc|}
\hline Water mass & $\begin{array}{c}\text { No. of } \\
\text { samples }\end{array}$ & $\begin{array}{c}\text { Depth } \\
(\mathrm{m})\end{array}$ & $\begin{array}{c}\text { Depth range } \\
(\mathrm{m})\end{array}$ & $\begin{array}{c}T \\
\left({ }^{\circ} \mathrm{C}\right)\end{array}$ & $\begin{array}{c}\sigma_{\tau} \\
\left(\mathrm{kg} \mathrm{m}^{-3}\right)\end{array}$ \\
\hline SSL & 33 & 100 & $90-110$ & $8.7(4.74)$ & $27.20(0.489)$ & $26003(38.4)$ \\
$\mathrm{O}_{2}$-min & 15 & 402 & $180-740$ & $7.9(2.39)$ & $27.32(0.194)$ & $187(51.2)$ \\
LSW & 32 & 1324 & $710-2090$ & $3.4(0.32)$ & $27.77(0.031)$ & $279(7.3)$ \\
NADW & 23 & 2537 & $1980-3250$ & $3.0(0.19)$ & $27.84(0.014)$ & $272(6.5)$ \\
DSOW & 22 & 3031 & $1220-3870$ & $1.9(0.42)$ & $27.91(0.24)$ & $288(12.7)$ \\
\hline
\end{tabular}

Table. 2. Prokaryotic and viral parameters in the western North Atlantic basin. PA: prokaryotic abundance; VA: viral abundance; V1: viral subgroup 1; V2: viral subgroup 2; V3: viral subgroup 3; VPR: virus-to-prokaryote ratio. SSL: subsurface layer; $\mathrm{O}_{2}$-min: oxygen minimum zone; LSW: Labrador Sea Water; NADW: North Atlantic Deep Water; DSOW: Denmark Strait Overflow Water. PHP and PA data are from Reinthaler et al. (2006). Numbers in parentheses: SD; letters in parentheses: Mann-Whitney tests of pairs of water masses (levels not connected by same letter are significantly different $[p<0.05])$. 
Table 3. Spearman rank correlations $(\rho)$ of parameters of the entire study. Values in bold: $p<0.05$; values in italics: $\rho>0.5$. Physico-chemical and prokaryotic data are from Teira et al. (2005) and Reinthaler et al. (2006). AOU: Apparent oxygen utilization; PA: prokaryotic abundance; PHP: prokaryotic heterotrophic production; VA: viral abundance; V1: viral subgroup 1; V2: viral subgroup 2; V3: viral subgroup 3; VPR: virus-toprokaryote ratio

\begin{tabular}{|c|c|c|c|c|c|c|c|c|c|c|c|c|c|}
\hline & Depth & Temp & Salinity & $\mathrm{O}_{2}$ & $\mathrm{AOU}$ & $\mathrm{PO}_{4}$ & $\mathrm{NO}_{3}$ & PHP & PA & VA & $\% \mathrm{~V} 1$ & $\% \mathrm{~V} 2$ & $\% \mathrm{~V} 3$ \\
\hline PA & -0.887 & 0.760 & 0.109 & -0.059 & -0.426 & -0.463 & -0.449 & 0.622 & & & & & \\
\hline VA & -0.508 & 0.411 & -0.104 & -0.101 & -0.349 & -0.314 & -0.284 & 0.474 & 0.450 & & & & \\
\hline$\% \mathrm{~V} 1$ & -0.239 & 0.249 & 0.209 & -0.216 & 0.078 & 0.096 & 0.097 & 0.235 & 0.076 & 0.390 & & & \\
\hline$\% \mathrm{~V} 2$ & 0.260 & -0.238 & -0.174 & 0.158 & 0.009 & -0.026 & -0.032 & -0.241 & -0.123 & -0.438 & -0.928 & & \\
\hline$\% \mathrm{~V} 3$ & -0.010 & -0.060 & -0.187 & 0.219 & -0.268 & -0.249 & -0.245 & -0.073 & 0.167 & -0.139 & -0.812 & 0.675 & \\
\hline VPR & 0.602 & -0.608 & -0.167 & 0.405 & -0.098 & 0.088 & 0.096 & -0.372 & -0.717 & 0.094 & 0.180 & -0.161 & -0.273 \\
\hline
\end{tabular}

Table 4. Spearman rank correlations ( $\rho$ ) of parameters in the North Atlantic Deep Water. Values in bold: $p<0.05$. Distance: distance from the stations closest to the Greenland-Iceland Ridge. Physico-chemical and prokaryotic data are from Teira et al. (2005) and Reinthaler et al. (2006). AOU:

Apparent oxygen utilization; PA: prokaryotic abundance; PHP: prokaryotic heterotrophic production; VA: viral abundance; V1: viral subgroup 1; V2: viral subgroup 2; V3: viral subgroup 3; VPR: virus-to-prokaryote ratio

\begin{tabular}{|c|c|c|c|c|c|c|c|c|c|c|c|c|c|}
\hline & Distance & Temp & Salinity & $\mathrm{O}_{2}$ & $\mathrm{AOU}$ & $\mathrm{PO}_{4}$ & $\mathrm{NO}_{3}$ & PA & PHP & VA & $\% \mathrm{~V} 1$ & $\% \mathrm{~V} 2$ & $\% \mathrm{V3}$ \\
\hline Temp & 0.556 & & & & & & & & & & & & \\
\hline Salinity & 0.624 & 0.623 & & & & & & & & & & & \\
\hline $\mathrm{O}_{2}$ & -0.824 & -0.730 & -0.859 & & & & & & & & & & \\
\hline $\mathrm{AOU}$ & 0.855 & 0.624 & 0.834 & 0.983 & & & & & & & & & \\
\hline $\mathrm{PO}_{4}$ & 0.872 & 0.760 & 0.814 & -0.942 & 0.029 & & & & & & & & \\
\hline $\mathrm{NO}_{3}$ & 0.861 & 0.792 & 0.821 & -0.938 & 0.915 & 0.988 & & & & & & & \\
\hline PA & -0.336 & -0.119 & -0.700 & 0.491 & -0.517 & -0.436 & -0.400 & & & & & & \\
\hline PHP & 0.014 & -0.134 & -0.140 & -0.040 & 0.076 & 0.041 & 0.045 & -0.182 & & & & & \\
\hline VA & -0.809 & -0.310 & -0.427 & 0.599 & -0.652 & -0.655 & -0.658 & 0.303 & 0.246 & & & & \\
\hline$\% \mathrm{~V} 1$ & 0.447 & 0.058 & 0.150 & -0.253 & 0.308 & 0.276 & 0.212 & -0.223 & 0.269 & -0.223 & & & \\
\hline$\% \mathrm{~V} 2$ & -0.527 & -0.177 & -0.245 & 0.337 & -0.382 & -0.373 & -0.314 & 0.284 & -0.260 & 0.230 & -0.927 & & \\
\hline
\end{tabular}




\begin{tabular}{|cccccccccccccc|}
\hline \%V3 & 0.082 & 0.174 & -0.006 & -0.002 & -0.008 & 0.119 & 0.123 & 0.036 & -0.151 & -0.051 & $\mathbf{- 0 . 5 5 2}$ & 0.275 & \\
VPR & $\mathbf{- 0 . 6 8 0}$ & -0.147 & -0.217 & 0.385 & -0.415 & $\mathbf{- 0 . 4 9 9}$ & $\mathbf{- 0 . 5 0 6}$ & 0.144 & 0.211 & $\mathbf{0 . 8 7 5}$ & -0.116 & 0.141 & -0.190 \\
\hline
\end{tabular}

702 Table 5. Prokaryotic and viral production, viral infection and virus-mediated mortality of prokaryotic plankton in the North Atlantic Deep Water

703 (NADW). Distance is given in km from the origin of NDAW in the Greenland-Iceland-Norwegian Sea. PHP: heterotrophic prokaryotic production;

704 VP: viral production; BS: burst size; FIC: fraction of visibly infected cells; VMMP: virus-mediated mortality of prokaryotes; VP: induced viral

705 production; FLC: fraction of lysogenic cells. ND: not determined; NA: not applicable

\begin{tabular}{|c|c|c|c|c|c|c|c|c|c|}
\hline Station & $\begin{array}{c}\text { Distance } \\
(\mathrm{km})\end{array}$ & $\begin{array}{c}\text { PHP } \\
\left(\times 10^{6} 1^{-1} \mathrm{~d}^{-1}\right)\end{array}$ & $\begin{array}{c}\mathrm{VP} \\
\left(\times 10^{7} 1^{-1} \mathrm{~d}^{-1}\right)\end{array}$ & $\mathrm{BS}$ & $\begin{array}{l}\text { FIC } \\
(\%)\end{array}$ & $\begin{array}{c}\text { VMMPVP } \\
(\%)\end{array}$ & $\begin{array}{c}\text { VMMPFIC }^{(\%)} \\
\text { (\%) }\end{array}$ & $\begin{array}{c}\mathrm{VP}_{\mathrm{i}} \\
\left(\times 10^{7} 1^{-1} \mathrm{~d}^{-1}\right)\end{array}$ & $\begin{array}{l}\text { FLC } \\
(\%)\end{array}$ \\
\hline 1 & 5500 & 2.95 & 0.23 & 24 & 11.7 & 3 & 15.2 & 0.06 & 5.8 \\
\hline 6 & 4800 & ND & 0.21 & ND & 8.3 & ND & 10.0 & 0.59 & 23.3 \\
\hline 9 & 4000 & 0.66 & 0.51 & ND & 0.6 & 32 & 0.6 & 3.83 & 4.5 \\
\hline 13 & 2900 & 1.23 & 0.98 & 28 & 15.6 & 28 & 22.2 & 1.88 & 29.9 \\
\hline 22 & 1400 & 0.21 & 0.80 & ND & 16.8 & 139 & 24.6 & 0.93 & 19.5 \\
\hline 27 & 670 & 1.16 & 1.49 & ND & 19.2 & 46 & 29.7 & 3.11 & 40.1 \\
\hline 31 & 200 & 0.79 & 2.40 & 33 & 22.0 & 108 & 36.6 & 1.66 & 15.2 \\
\hline Average & NA & 1.17 & 0.95 & 28 & 13.5 & 59 & 19.9 & 1.72 & 20.5 \\
\hline SD & NA & 0.94 & 0.78 & 5 & 7.3 & 53 & 12.2 & 1.36 & 13.8 \\
\hline
\end{tabular}


Fig. 1. Study area in the North Atlantic Ocean. Dots: individual stations sampled during the TRANSAT-II

Fig. 2. Distribution of prokaryotic and viral parameters along the TRANSAT-II cruise in the North Atlantic. Dots: sampling locations; V1, V2 and V3 are viral subgroups 1, 2 and 3, respectively

Fig. 3. Variation of viral abundance, virus-to-prokaryote ratios (VPR) and 2 viral subgroups (as determined by flow cytometry) in the North Atlantic Deep Water with distance from its formation in the Greenland-Iceland-Norwegian (GIN) Sea. (A) Viral abundance $(\mathrm{p}<0.0001)$; (B) VPR ( $<$ 0.0001); (C) viral subgroup 1 (V1) ( $<<0.005)$; (D) viral subgroup 2 (V2) $(p<0.01)$. Regression parameters are given in the plots

Fig. 4. Variation of viral production, the fraction of infected cells (FIC), induced viral production $\left(\mathrm{VP}_{\mathrm{i}}\right)$ and fraction of lysogenic cells (FLC) in the North Atlantic Deep Water with distance from its formation in the Greenland-Iceland-Norwegian (GIN) Sea. Data are averages \pm range of duplicate incubations. (A) Viral production ( $\mathrm{p}=0.0005)$; (B) FIC ( $<<0.05)$; (C) $\mathrm{VP}_{\mathrm{i}}$; (D) FLC. Regression parameters are given in the plots 